\title{
A new Permian bivalve-dominated assemblage in the Rio do Rasto Formation, Paraná Basin, Brazil: Faunal turnover driven by regional- scale environmental changes in a vast epeiric sea
}

\author{
Marcello Guimarães Simões a, *, Suzana Aparecida Matos ${ }^{\text {b }}$, Luiz Eduardo Anelli ${ }^{\text {, }}$, \\ Rosemarie Rohn ${ }^{\mathrm{d}}$, Lucas Veríssimo Warren ${ }^{\mathrm{d}}$, Juliana Machado David ${ }^{\mathrm{b}}$ \\ a Instituto de Biociências, Departamento de Zoologia, Universidade Estadual Paulista, Distrito de Rubião Junior, Botucatu, SP, 18.618-970, Postal Code 510 \\ Brazil \\ b Instituto de Geociências, Programa de Pós-graduação em Geoquímica e Geotectônica, Universidade de São Paulo, SP, 05508-080, Brazil \\ ${ }^{c}$ Instituto de Geociências, Departamento de Geologia Sedimentar e Ambiental, Universidade de São Paulo, SP, 05508-080, Brazil \\ d Instituto de Geociências e Ciências Exatas, Departamento de Geologia Aplicada, Universidade Estadual Paulista, Campus de Rio Claro, Rio Claro, SP, 13506- \\ 900 Postal Code 178, Brazil
}

\section{A R T I C L E I N F O}

\section{Article history:}

Received 15 July 2015

Received in revised form

26 August 2015

Accepted 11 September 2015

Available online 14 September 2015

\section{Keywords}

Permian

Faunal turnover

Climate change

Freshening events

Benthic assemblages

\begin{abstract}
A B S T R A C T
The basal portion of the Permian Rio do Rasto Formation (Serrinha Member), Passa Dois Group, Paraná Basin, Brazil, records an entirely new bivalve fauna intercalated between the underlying Pinzonella neotropica assemblage (uppermost portion of the Teresina Formation) and the overlying Leinzia similis assemblage (Rio do Rasto Formation). Mollusks of these assemblages lived in marginal shallow-water habitats of an immense epeiric sea and were dominated by endemic bivalve species. Taxonomic analysis revealed the presence of Terraia curvata (60.61\%), Astartellopsis prosoclina (19.70\%), Cowperesia emerita (10.61\%), Leinzia curta (4.55\%), Terraia bipleura (3.03\%) and Beurlenella elongatella (1.52\%), which are associated with conchostracans and plant remains. Species composition, abundance, and dominance in this novel assemblage differ notably from the preceding ones, suggesting a substantial evolutionary turnover. Regional-scale environmental changes recognized based on taphonomy, facies analysis, and geochemical data consist of progressive freshening of the marginal habitats of the Paraná Basin and taxic changes that include the following: (a) loss of genera, (b) decrease in bivalve abundance and ecological guilds, (c) disappearance of the dominant bivalve group (Pinzonellinae) and (d) diversification of Terrainae bivalves. The ecological signature also changed notably because only infaunal suspension-feeding bivalves are present, indicating a significant loss of functional diversity at the regional scale. Likely stressor factors (among others) are tied to freshening events, suggesting profound changes in (a) salinity, (b) primary productivity and (c) a lack of coarse, stable substrates coupled with high bioturbation rates. Hence, our regional example could offer valuable clues to benthic (bivalve) community responses in a habitat subjected to (a) rapid climate changes and (b) freshening events in shallow-water settings. Finally, the stratigraphic range of the dominant species (T. curvata) appears to be restricted to the basal portion of the Rio do Rasto Formation. Based on the presence of this species and of $C$. emerita, the novel assemblage is tentatively correlated with that of the Permian Gai-As Formation in the Huab region of Namibia, thus supporting previous assumptions of a seaway connecting both basins during the Guadalupian Epoch.
\end{abstract}

() 2015 Elsevier Ltd. All rights reserved.

\footnotetext{
* Corresponding author.

E-mail addresses: profmgsimoes@gmail.com (M.G. Simões), sumatos.s@gmail. com (S.A. Matos), anelli@usp.br (L.E. Anelli), rohn@rc.unesp.br (R. Rohn), warren@ rc.unesp.br (L.V. Warren), julianamdavid@gmail.com.br (J.M. David).
}

\section{Introduction}

Permian bivalve mollusks of the Passa Dois Group in the Paraná Basin (see syntheses in Simões et al., 1998 and Wesselingh, 2007) of Brazil represent a distinct chapter in the evolutionary history of the Class Bivalvia (Runnegar and Newell, 1971). The fauna is known 
worldwide due to its diversity, disparity and endemicity. According to current knowledge, this molluscan fauna can be arranged in ascending order into five distinct assemblages (sensu Kidwell et al., 1986) as follows (Rohn, 1994; Simões et al., 1998): Anhembia froesi (Serra Alta Formation), Pinzonella illusa (Teresina Formation), Pinzonella neotropica (Teresina Formation), Leinzia similis (Rio do Rasto Formation, Serrinha Member), and Palaeomutela? platinensis (Rio do Rasto Formation, Morro Pelado Member) (Fig. 1). These indigenous bivalves evolved in a large epeiric sea $\left(\sim 1.6\right.$ million $\left.\mathrm{km}^{2}\right)$ comparable in area only with the Miocene Pebas lake system $(\sim 1.1$ million $\mathrm{km}^{2}$ ) (Wesselingh et al., 2002; Wesselingh, 2008). Pronounced paleo-environmental changes occurred in the Paraná Basin during the Cisuralian-Lopingian Epochs, when these bivalves flourished in a confined aquatic environment with restricted circulation, variable salinity and distinct substrate types (Beurlen, 1954; Runnegar and Newell, 1971; Simões et al., 1998; Alessandretti et al., 2015, Fig. 10).

The Permian endemic bivalve fauna of the Passa Dois Group is believed to be the oldest known example of a molluscan fauna that thrived in intracratonic sedimentary basins (Wesselingh, 2007, p. 289). However, several Permian bivalve assemblages of the Passa Dois Group remain undescribed or poorly studied, which hampers our understanding of their evolutionary history and biodiversity. Indeed, an analytical bias (sensu Fürsich and Aberhan, 1990) exists in the study of those bivalves because most of the available investigations focused on well preserved fossil occurrences of the Teresina and Corumbataí formations in the middle portion of the Passa Dois Group. In contrast, much less is known of the bivalve assemblages in the upper portion of the Passa Dois Group, the Rio do Rasto Formation, where the L similis and Palaeomutela? platinensis assemblages are recorded (Fig. 1). Hence, the fossil material described herein represents an entirely new bivalve assemblage in the sedimentary succession of the Passa Dois Group of Brazil. The assemblage is recorded in the basal part of the Rio do Rasto Formation, which is initially marked by the deposition of sandstones and mudstones in a storm-influenced epeiric sea system (Fig. 1) with occasional fluvial incursions. At the top of the studied succession, sandstones and certain mudstone intercalations generated in shallow deltaic and eolian settings are recorded (Lavina, 1991; Rohn, 1994; Rohn et al., 2003; Warren et al., 2008; Holz et al., 2010; Schemiko et al., 2014). During these intervals, sedimentation was dominated by arid or semiarid conditions throughout the major portions of the southern South America continent (Limarino et al., 2014). In other words, the studied assemblage is tied to the period of progressive continentalization and growing aridization of the Paraná Basin (see Simões et al., 1998; Warren et al., 2008) extending from the late Guadalupian to the early Lopingian, possibly to the end of the Permian at subsurface. Therefore, this paleoenvironmental scenario is completely distinct from that observed in the basal and middle portions of the Passa Dois Group (i.e., Serra Alta and Teresina formations), when storm-influenced offshore-to-coastal-plain settings prevailed in the Paraná Basin (Holz et al., 2010; Warren et al., 2015). In this context, the current contribution sheds light on the evolution of the Passa Dois Group bivalves and records an extreme faunal turnover tied to the continentalization phase of the central-western Gondwana basins with a profound influence on bivalve assemblage composition, abundance, and dominance.

\subsection{Background}

Detailed field-works conducted by one of the authors ( $R$. Rohn) during the 1980s and 1990s in the outcrop belt of the Passa Dois Group of southern Brazil revealed numerous ( 125) new fossil

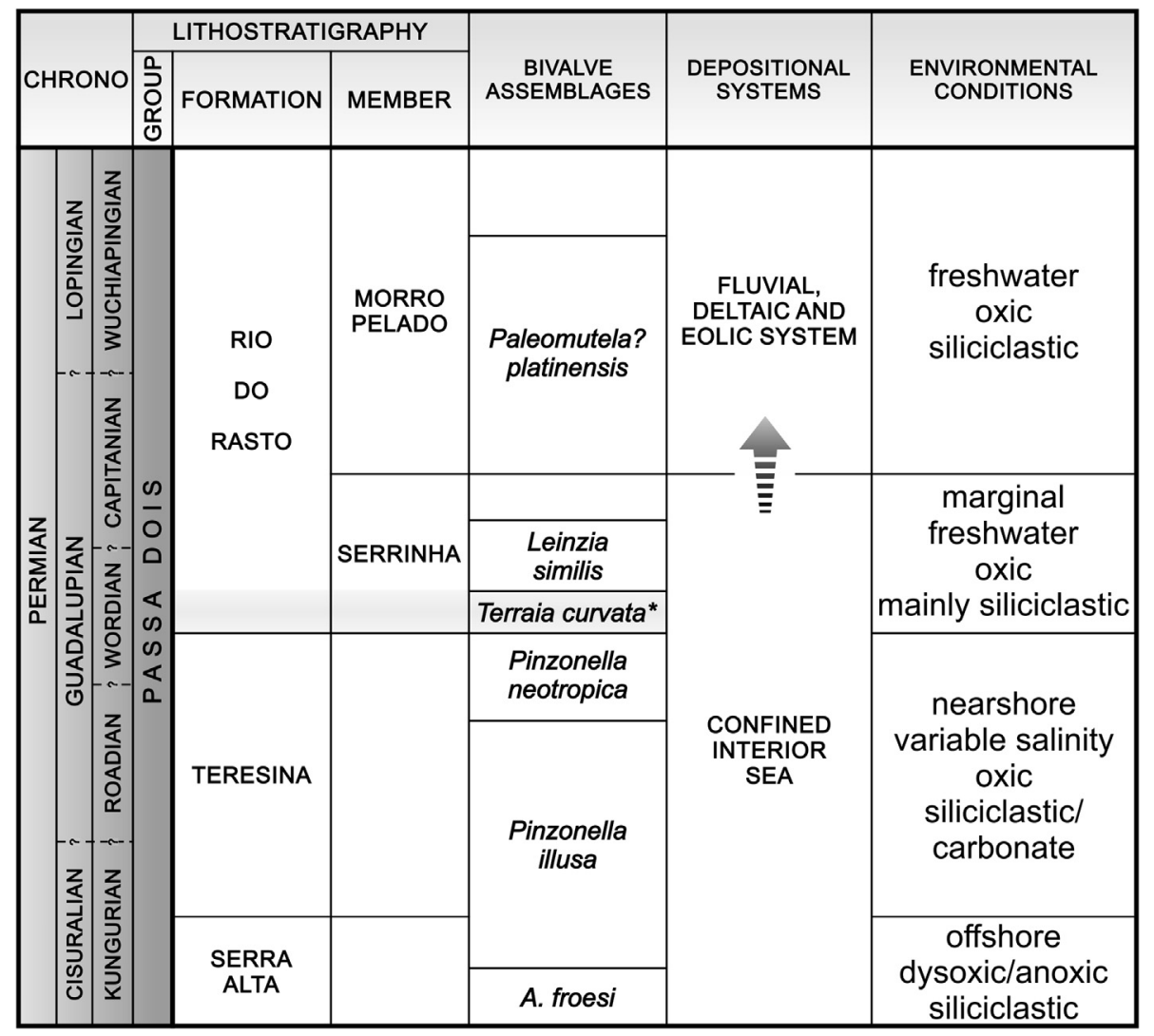

Fig. 1. Schematic chart of the Passa Dois Group, Permian at the eastern margin of the Paraná Basin, showing the bivalve assemblages (based on Rohn, 1994, 2007). 
occurrences in the Rio do Rasto Formation (Rohn, 1988, 1994, p. 52). Among these, one in the basal part of the Rio do Rasto Formation (Serrinha Member) is particularly noteworthy and is recorded along the geological section between Cândido de Abreu and Reserva, State of Paraná (Fig. 2). Previously, all recorded bivalves in the Serrinha Member were assigned to the $L$. similis assemblage (see discussions in Rohn, 1994 and Simões et al., 1998), which was first discovered by Mendes (1954). However, based on the available stratigraphic information, Rohn and Simões (1997) suggested that such bivalves might be slightly older than those recorded in the L. similis assemblage (Fig. 1). Still, these authors pointed to the fact that such an occurrence might represent an entirely novel assemblage intercalated between the $P$. neotropica assemblage below (uppermost portion of the Teresina Formation) and the L. similis assemblage above (Fig. 1). The best records of this occurrence are the rocks of the Rio do Rasto Formation cropping-out along the geological section in the PR-239 road (Fig. 2). Bivalves are recorded $\sim 25 \mathrm{~m}$ above the last occurrences of P. neotropica (Rohn, 1994, p. 143). In that locality, meter-thick beds of greenish and bioturbated shales contain abundant bivalve shells (as internal and external molds), some of which were excellently preserved. The shells are directly associated with complete conchostracan shells, and plant remains (Glossopteridales and ferns) are common at the top of the unit (Rohn, 1994). A brief inspection of the bivalve shells revealed the presence of Terraia curvata and Cowperesia emerita, among other undescribed shells. Therefore, this new bivalve occurrence is of high biostratigraphic and paleogeographic significance because C. emerita and T. curvata were previously recorded in the Permian Gai-As Formation of Namibia (David, 2010; David et al., 2011). Thus, in this contribution, we formally describe the bivalve shells of a novel assemblage and discuss their regional paleoecological and biostratigraphical meaning. Finally, we show how climate-driven changes can influence a local benthic community, thus shedding light on future scenarios and likely responses of the bivalve fauna to freshening events in marginal marine habitats.

\section{General geological setting}

In the Brazilian part of the Paraná Basin (i.e., the largest Paleozoic basin of South America), the upper portion of the Permian succession is referred to the 1400 -m-thick Passa Dois Group (Figs. 1 and 3), which includes (in ascending order) the Late Artinskian Irati Formation, the Kungurian Serra Alta Formation, the Late Kungurian-Roadian Teresina Formation and the CapitanianWuchiapingian Rio do Rasto Formation (Rohn, 1994, 2007; Holz et al., 2010). This last unit has been subdivided into the basal Serrinha Member (100-250 m thick) and the Morro Pelado Member (250-300 m thick) (Holz et al., 2010; Alessandretti et al., 2015, in press). Greenish sandstones, siltstones and mudstones characterize the Serrinha Member and are generally organized in tabular

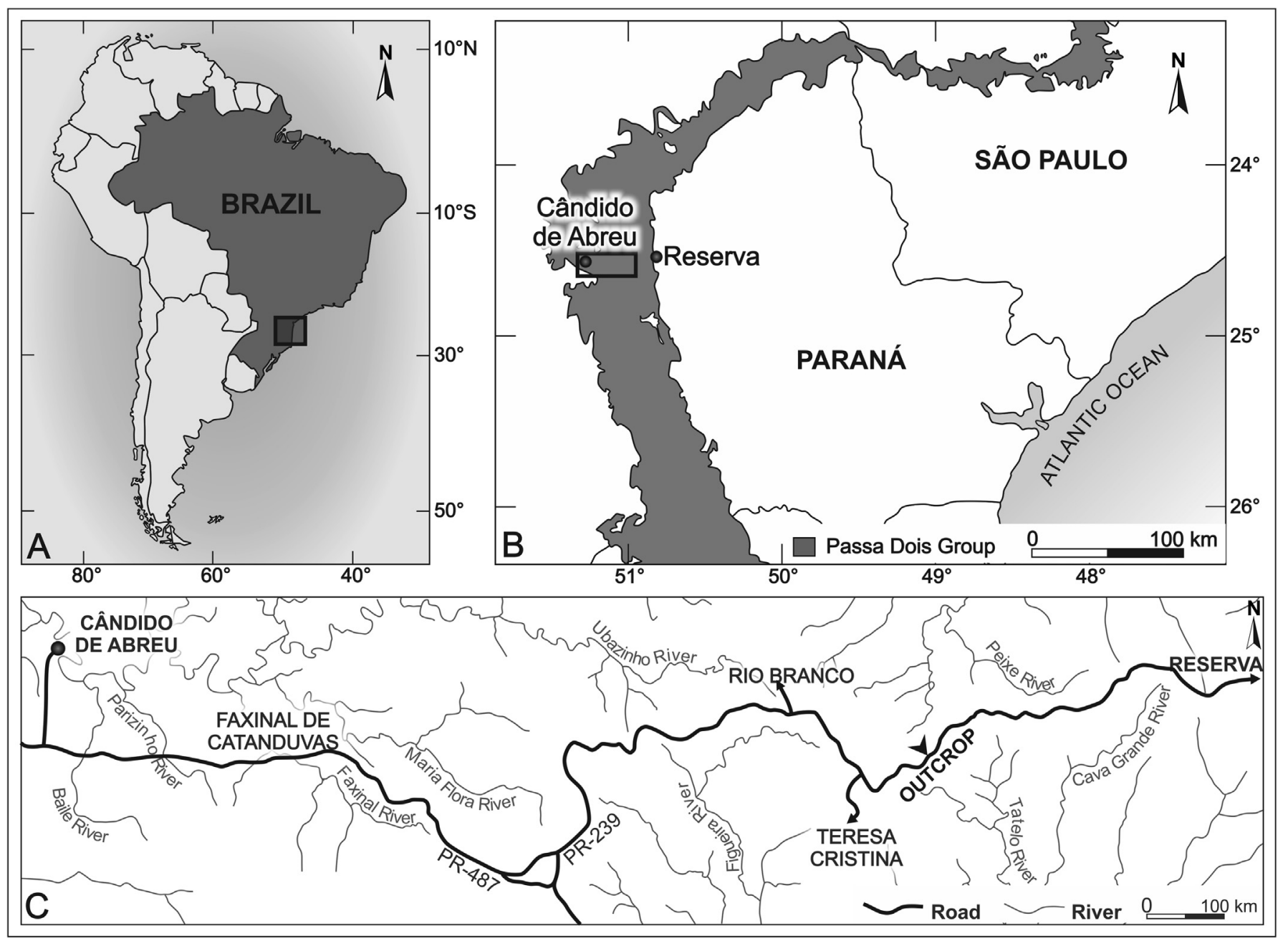

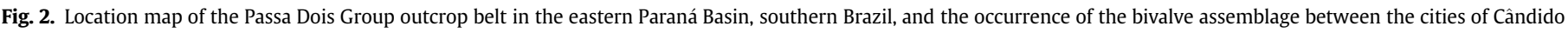
de Abreu and Reserva, State of Paraná (modified from Rohn, 1994; Ferreira-Oliveira and Rohn, 2010). 


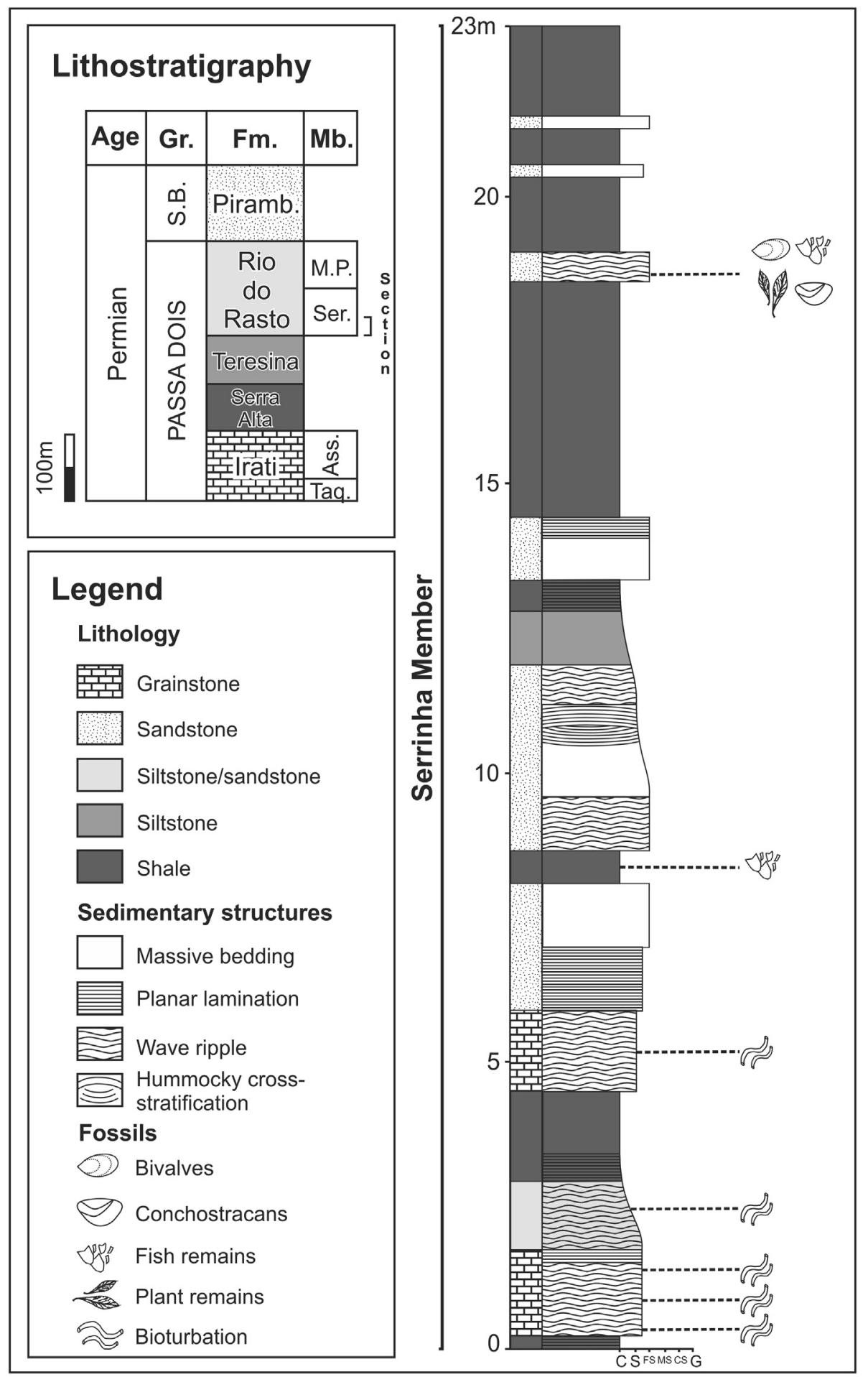

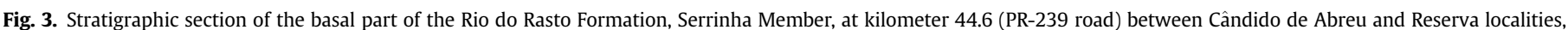

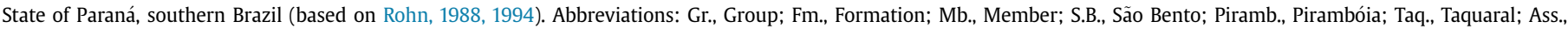
Assistência; Ser., Serrinha; M.P., Morro Pelado.

strata. These rocks were deposited in a large and shallow epeiric water body influenced by storms (Warren et al., 2008; Alessandretti et al., 2015). However, reddish fine sandstone and mudstones that compose the Morro Pelado Member were interpreted as deposited under proximal deltaic and eolian settings (Rohn, 1994; Warren et al., 2008; Holz et al., 2010; Schemiko et al., 2014).

The newly described bivalve-dominated assemblage was recorded in heterolithic and mudstone facies of the basal portion of the Serrinha Member (Fig. 3). In Paraná State, the unit occurs immediately above the siltstones of the Teresina Formation, suggesting a transitional contact marked by the gradual appearance of sandstone facies (see also Rohn, 2007, p. 155). The coarseningupward pattern observed in the transition between the units culminates in an aggradational to progradational succession 
characterized by mm-to-m thick intercalation of fine sandstones, mudstones, and heterolithic tabular beds (Warren et al., 2008). The sandstone facies commonly show wave ripples, planar lamination and locally, swaley and hummocky cross-stratification interbedded with highly bioturbated siltstones and flaser-to-linsen heterolithic facies. Relatively common sinuous traces such as Palaeophycus and simple to spreiten-bearing U-shaped traces such as Arenicolites and Diplocraterion have been noted (Warren, 2005). Certain bioclastic, rich, and densely packed bone beds occur sporadically interbedded with the heterolithic and sandstone facies and are composed of the scales and teeth of paleoniscid fishes and phosphatized coprolites. The facies association of the Serrinha Member suggests a scenario characterized by the episodic deposition of tempestites in an offshore setting marked by oxygenated bottom conditions (Warren et al., 2008; Alessandretti et al., 2015). The sporadic occurrences of mud-crack-like structures in the basal portion of the unit were interpreted as seismites by Warren (2005). Hence, these structures are not indicative of subaerial exposure, as previously inferred by certain authors (Schneider et al., 1974; Gama Jr., 1979; Lavina, 1991; Rohn, 1994).

A discernable change in the color of the pelitic facies (from gray to red and purple) and an increase in the thickness and frequency of lenticular beds of fine-grained sandstones occur at the top of the Serrinha Member. These features indicate the transition to a deltaic and eolian setting of the Morro Pelado Member (Lavina, 1991; Rohn, 1994; Warren et al., 2008; Schemiko et al., 2014).

The studied succession (Figs. 2 and 3 ) occurs as a long roadside exposure at kilometer 44.6 of the PR-239 highway located between the towns of Cândido de Abreu and Reserva in Paraná State of Brazil (Fig. 2). According to Rohn (1994), the most abundant rock type is a greenish fossiliferous mudstone that gradates upwards to heterolithic rocks with wavy bedding (Fig. 3). Compact calcareous sediments, mudstones lenses and fine sandstone with hummocky cross-stratification and planar lamination characterize this succession (Rohn, 1994), but bioturbation is commonly recorded at the base of the outcrop (Fig. 3). The bivalve fossils are found in a greenish-gray heterolithic facies located in the uppermost portion of the succession. Closed articulated shells are common, and signs of fragmentation, bioerosion, and encrustation are lacking. However, selected shells (Beurlenella elongatella) might be preserved in situ (Anelli et al., 2010). The bivalves are commonly associated with well preserved shells of conchostracans.

\section{Material and methods}

The material studied in this work was originally collected by R. Rohn during the 1980s and 1990s and are housed in the Institute of Geosciences and Exact Sciences of São Paulo State University (UNESP) in Rio Claro, São Paulo State, under the code URC-MB. The material is composed of $\sim 60$ specimens primarily represented by internal and external molds. Laboratory preparation includes plasticine casts (FIMO brand) and magnesium coating to enhance the internal anatomical characters of the shells, such as muscle scars and hinge structures. The suprageneric systematics is based on Morris et al. (1991) and Carter et al. (2011). The morphological terminology and systematic classification of carditids and pachydomids are based on Mendes (1952), Runnegar and Newell (1971), Runnegar (1974) and Simões et al. (1997). Determination of elongation and obesity indices follow Stanley (1970). The bivalve mode of life was interpreted based on Stanley (1970) and Ghilardi (1999), and the ecological guilds (inferred lifestyle) were determined according to Aberhan and Kiessling (2015, p. 2), including: epifaunal, stationary, byssate, suspension feeders (ESBSF); epifaunal, stationary, unattached, suspension feeders (ESUSF); semi-infaunal, stationary, byssate suspension feeders (SISBSF); semi-infaunal, facultatively motile, suspension feeders (SIFMSF); semi-infaunal, stationary, byssate, suspension feeders (SMSBSF); shallow infaunal, facultatively motile, unattached, suspension feeders (SIFMUSF); shallow infaunal, facultatively motile, chemosymbionts (SIFMC); intermediate infaunal, facultatively motile, unattached, suspension feeders (IIFMUSF); and deep infaunal, facultatively motile, suspension feeders (DIFMSF).

\section{Systematic paleontology (by J.M. David, L.E. Anelli and M.G. Simões)}

Infraclass HETEROCONCHIA Hertwig, 1895.

Cohort CARDIOMORPHI Férussac, 1822.

Subcohort CARDITIONI Dall, 1889.

Order CARDITIDA Dall, 1889.

Superfamily CRASSATELLOIDEA Férussac, 1822.

Family TERRAINAE Scarlato and Starobogatov, 1979.

Terraia Cox, 1934

Type species. Terraia altissima (Holdhaus, 1918).

Terraia curvata (Reed, 1929) (Fig. 4)

Isocyprina curvata Reed, 1929, p. 12.

Terraia sp. cf. Terraia curvata: David et al., 2011, p. 6, Fig. 4.

Material. Thirty nine internal molds (URCMB-300 2a, 2b, 4, 7, 21, 23, 27a, 31a, 31b, 31e, 32, 34a, 34b, 39, 43, 44, 48a, 48d, 55, 61a, 69a, 71a, 71c, 82, 93, 97a, 98, 99a, 100, 116, 121, 125, 144a, 146, 151, 154, 158a, 158b, 159) and one external mold (URCMB-300 5a).

Locality and unit. Road PR-239, km 44.6, Passa Dois Group, Serrinha Member, Rio do Rasto Formation, Paraná Basin, Brazil.

Age. Permian, Guadalupian.

Description. Shell small, inequilateral, equivalved, moderately elongate to elongate (Table 1). Umbones high, pointed and prosogyrate, with subcentral beaks. Anterior dorsal margin rounded; ventral margin convex; posterior dorsal margin arched, descending steeply to a small obliquely truncated posterior margin. Two rounded posterior umbonal carinae are present, the first one extending from the umbonal region to the postero-ventral angle and the second very close to the posterior dorsal margin. Hinge plate of right valve with a large and well defined triangular tooth, bordered at both sides by depressions in the thickened hinge plate. Hinge plate of the left valve with corresponding triangular socket bordered in both sides by a hinge plate thickening. External surface of the valve covered with fine growth lines. Muscle impressions were not observed.

Discussion. The material resembles Isocyprina curvata (Reed, 1929) in shell shape and internal characters (i.e., hinge), which occurs in deposits of the basal part of the Rio do Rasto Formation. Mendes (1954) suggested that I. curvata might be a subjective synonym of Terraia altissima, but Beurlen (1954) argued that T. curvata differs from $T$. altissima by its very posteriorly elongated shell, with subcentral umbones and an arched posterior dorsal margin. Our material exhibits most of the characters summarized by Reed (1929) and Beurlen (1954) and thus is assigned to T. curvata.

Terraia bipleura (Reed, 1929) (Fig. 5D)

?Pleurophorus bipleura Reed, 1929, p. 47, pl. 4, Figs. 8-10.

Terraia bipleura: Runnegar and Newell, 1971, p.53, Fig. 23.

Material. Two internal molds (URCMB-300, 11, 93).

Locality and unit. Road PR-239, km 44.6, Passa Dois Group, Serrinha Member, Rio do Rasto Formation, Paraná Basin, Brazil.

Age. Permian, Guadalupian.

Description. Shell small, equivalved, inequilateral, moderately elongate (Table 2). Umbones low, subcentral. Anterior dorsal 

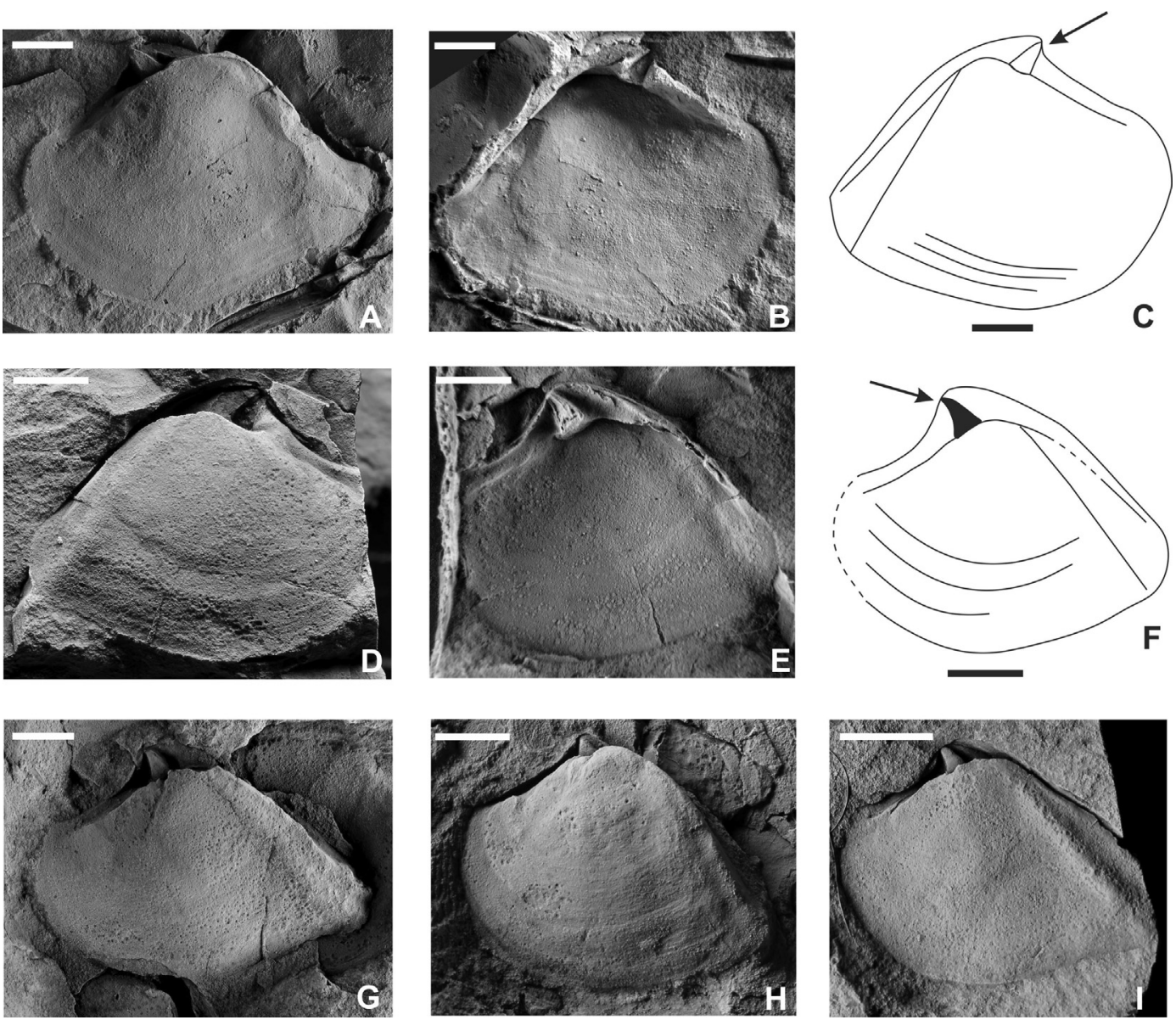

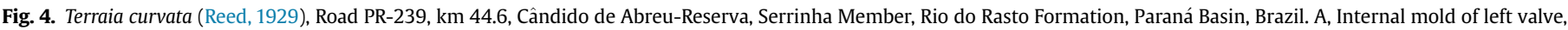

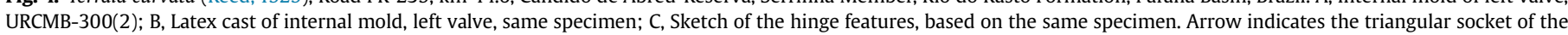

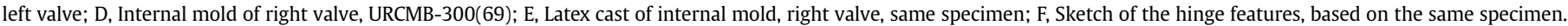

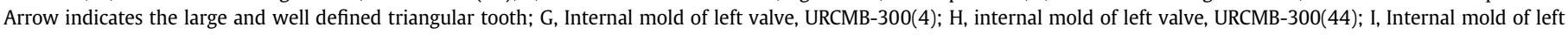
valve, URCMB-300(82). All scale bars $=0.5 \mathrm{~cm}$.

margin concave; ventral margin convex; posterior dorsal margin slightly convex. Two well-defined posterior umbonal carinae running from umbonal region to the posterior margin. Shell surface covered with fine growth lamellae. Hinge and musculature features were not observed.

Discussion. Terraia bipleura is usually found in sedimentary rocks of the Serrinha Member, Rio do Rasto Formation. It was first described as ?Pleurophorus bipleura (Reed, 1929) and tentatively regarded as a junior synonym of T. altissima by Mendes (1954). Indeed, the hinge of $T$. bipleura is very similar to that of $T$. altissima, but the second umbonal carina of $T$. bipleura does not coincide with the posterior dorsal margin of the valve, as in T. altissima (see also Runnegar and Newell, 1971). Our material closely resembles that figured by Runnegar and Newell (1971, p. 53) as T. bipleura, especially the distinct carinae and the wide area behind the second umbonal carina.

\section{Astartellopsis Beurlen, 1954}

Type species. Astarte cf. triasina Roemer: Reed, 1929, pl. 49, pl. 3, Figs. 2-8.

Astartellopsis prosoclina Beurlen, 1954 (Fig. 5A-C)

Astartellopsis prosoclina: Runnegar and Newell, 1971, p. 57.

Material. Thirteen internal molds (URCMB-300 5b, 6, 19, 30a, 30b, 33, 45, 48b, 53, 61b, 67a, 89, 133).
Locality and unit. Road PR-239, km 44.6, Passa Dois Group, Serrinha Member, Rio do Rasto Formation, Paraná Basin, Brazil.

Age. Permian, Guadalupian.

Description. Shell small, triangular, equivalved, inequilateral, equant (Table 3). Umbones high, pointed and prosogyrate, with subcentral beaks. A posterior umbonal carina is weakly developed coinciding with the posterior dorsal margin of the valve. Posterior dorsal margin concave; anterior dorsal margin convex; ventral margin concave. Hinge plate of the right valve with a massive and curved cardinal tooth, bordered on both sides by a thickened hinge plate. Anterior adductor muscle scar oval, located next to the anterior dorsal margin. External surface of the valve covered with fine growth lines.

Discussion. Reed (1929) proposed Astarte cf. triasina for some specimens found in rocks of the Serrinha Member, Rio do Rasto Formation. Later, Beurlen (1954) analyzed some bivalve material from the Passa Dois Group in the Paraná State and erected a new genus and species, Astartellopsis prosoclina, for Reed's material. Runnegar and Newell (1971) validated Beurlen's designation. Rohn (1994) suggested that $A$. prosoclina could be a junior synonym of $T$. curvata, but in our view the species differs from T. curvata in external shell characters especially in the position of the carina. Also, the cardinal tooth in A. prosoclina is more pronounced than that of $T$. curvata. Our material resembles that illustrated and described by Beurlen (1954, Figs. 4-33, Figs. 5-45, 46, 47), in shell 
Table 1

Measurements of Terraia curvata (Reed, 1929).

\begin{tabular}{|c|c|c|c|}
\hline Specimen code & Length (mm) & Height (mm) & Elongation $\mathrm{L} / \mathrm{H}$ \\
\hline URCMB-300(2a) & 39.7 & 31.8 & 1.24 \\
\hline URCMB-300(2b) & - & 31.1 & - \\
\hline URCMB-300(4) & 29.0 & 20.8 & 1.39 \\
\hline URCMB 300(5a) & 30.0 & 20.7 & 1.44 \\
\hline URCMB-300(7) & - & - & - \\
\hline URCMB-300(21) & 23.4 & 19.5 & 1.20 \\
\hline URCMB-300(23) & - & - & - \\
\hline URCMB-300(27a) & 35.5 & 21.6 & 1.64 \\
\hline URCMB-300 (31a) & - & - & - \\
\hline URCMB-300(31b) & - & - & - \\
\hline URCMB-300(31e) & 12.7 & 8.4 & 1.51 \\
\hline URCMB-300(32) & - & - & - \\
\hline URCMB-300(34a) & - & 28.9 & - \\
\hline URCMB-300(34b) & - & 27.7 & - \\
\hline URCMB-300(39) & - & - & - \\
\hline URCMB-300(43) & 26.7 & 18.5 & 1.44 \\
\hline URCMB-300(44) & 24.5 & 19.7 & 1.24 \\
\hline URCMB-300(48a) & 23.0 & 18.1 & 1.27 \\
\hline URCMB-300(48d) & 42.4 & 30.0 & 1.41 \\
\hline URCMB-300(55) & - & 17.0 & - \\
\hline URCMB-300(61a) & 16.1 & 12.5 & 1.28 \\
\hline URCMB-300(69a) & - & 20.5 & - \\
\hline URCMB-300(71a) & - & 16.8 & - \\
\hline URCMB-300(71c) & 28.7 & 19.8 & 1.44 \\
\hline URCMB-300(82) & 20.2 & 15.1 & 1.33 \\
\hline URCMB-300(93) & - & - & - \\
\hline URCMB-300(97a) & - & 25.4 & - \\
\hline URCMB-300(98) & 28.8 & 19.2 & 1.50 \\
\hline URCMB-300(99a) & - & 15.4 & - \\
\hline URCMB-300(100) & - & - & - \\
\hline URCMB-300(116) & - & 19.1 & - \\
\hline URCMB-300(121) & - & - & - \\
\hline URCMB-300(125) & - & - & - \\
\hline URCMB-300(144a) & 33.2 & 22.2 & 1.49 \\
\hline URCMB-300(146) & - & 18.0 & - \\
\hline URCMB-300(151) & - & 12.1 & - \\
\hline URCMB-300(154) & 41.9 & 30.0 & 1.39 \\
\hline URCMB-300(158a) & 20.7 & 12.8 & 1.61 \\
\hline URCMB-300(158b) & 28.3 & 22.4 & 1.26 \\
\hline URCMB-300 (159) & 36.7 & 26.9 & 1.36 \\
\hline
\end{tabular}

shape and hinge features. In particular the massive cardinal tooth of the right valve is identical to that recorded in Beurlen's specimens.

Subcohort CARDIONI Férussac, 1822.

Infrasubcohort CARDIIDIA Férussac, 1822.

Megaorder POROMYATA Ridewood, 1903.

Order PHOLADOMYIDA Newell, 1965.

Superfamily PHOLADOMYOIDEA King, 1844.

Family PHOLADOMYIDAE King, 1844.

Leinzia Mendes, 1949

Type species. Solenomorpha similis Holdhaus, 1918, by original designation.

Leinzia curta Beurlen, 1954 (Fig. 5F)

Material. Two internal molds (URCMB-300 14a, 14b) and one external mold (URCMB-300 68).

Locality and unit. Road PR-239, km 44.6, Passa Dois Group, Serrinha Member, Rio do Rasto Formation, Paraná Basin, Brazil.

Age. Permian, Guadalupian.

Description. Shell small, inequilateral, posteriorly expanded, equivalved, moderately elongate (Table 4). Umbones low, prosogyrate, with subcentral beaks. Anterior dorsal margin rounded; ventral margin weak convex; posterior dorsal margin. A wellmarked umbonal carina is present, delimiting a small respiratory margin with the extremity of the posterior dorsal margin. Hinge plate of the right valve with a triangular cardinal tooth immediately below beaks. Hinge plate of left valve with corresponding triangular socket. External surface of the valve covered with regularly spaced commarginal rugae. Muscle impressions were not observed.

Discussion. Leinzia curta was first described by Beurlen (1954) from the Serrinha Member, Rio do Rasto Formation. He suggested that this species might be related to precursor forms of $L$. similis, since the two species are very similar. $L$. curta resembles $L$. similis but the former exhibits a very rounded anterior dorsal margin, lacking the rostrum that characterizes the latter species. David et al. (2011) suggested that forms described as Huabiella compressa in Namibian deposits could be related to L. curta of the Passa Dois Group. However, the hinge of $H$. compressa was interpreted as edentulous, while a triangular cardinal tooth in the right valve is present in our specimens of $L$. curta (see also Beurlen, 1954). The characteristic ornamentation of regularly spaced commarginal rugae and the hinge features are identical to those of $L$. curta illustrated by Beurlen (1954).

Megaorder SOLENATA Dall, 1889.

Order HIATELLIDA Carter et al., 2011.

Superfamily EDMONDIOIDEA King, 1850.

Family PACHYDOMIDAE Fischer, 1887.

Subfamily PACHYDOMINAE Fischer, 1887.

Tribe PLESIOCYPRINELLINI Simões et al., 1997.

Beurlenella Anelli et al., 2010

Type species. Beurlenella elongatella Anelli et al., 2010, p. 15, Figs. 1 and 2.

Beurlenella elongatella Anelli et al., 2010 (Fig. 5G-I)

Examined Material. One internal mold of articulated shell (URCMB-300 58).

Locality and unit. Road PR-239, km 44.6, Passa Dois Group, Serrinha Member, Rio do Rasto Formation, Paraná Basin, Brazil.

Age. Permian, Guadalupian.

Comments. The material here examined (Table 5) surely refers to the pachydomid (=Plesiocyprinellini) B. elongatella Anelli et al., 2010, from the Serrinha Member, Rio do Rasto Formation. The specimen has a well-defined blunt tooth in the right valve and a well-defined socket in the left valve.

Cowperesia Mendes, 1952

Type species. Cowperesia anceps Mendes, 1952, p. 88, pl. 2, Fig. 3a, b, pl. 4, Figs. 2a-5b.

Cowperesia emerita (Reed, 1929) (Fig. 5E)

Pseudocorbula emerita Reed, 1929, pl. 2, Figs. 4-6.

Cowperesia emerita: Mendes, 1954, pl. 3, Fig. 9.

Leptoterraia emerita: Runnegar and Newell, 1971, p. 37.

Cowperesia emerita: David et al., 2011, p. 12, Fig. 6.

Material. Three internal molds (URCMB-300 28, 36, 93b) and four external molds (URCMB-300 21, 31d, 52, 77).

Locality and unit. Road PR-239, km 44.6, Passa Dois Group, Serrinha Member, Rio do Rasto Formation, Paraná Basin, Brazil.

Age. Permian, Guadalupian.

Description. Shell small, subtriangular, equivalved, equilateral, equant (Table 6). Umbones low with central beaks. Two well defined and slightly curved posterior umbonal carinae run from the umbonal region to the postero-ventral angle and close to the postero-dorsal margin, respectively. Anterior dorsal margin straight; anterior margin rounded; posterior margin straight. External ornament of fine, commarginal growth lines, superimposed by widely spaced, broad co-marginal rugae, also apparent on internal molds. Hinge features and muscle impressions not observed.

Discussion. The genus Cowperesia was first proposed by Mendes 

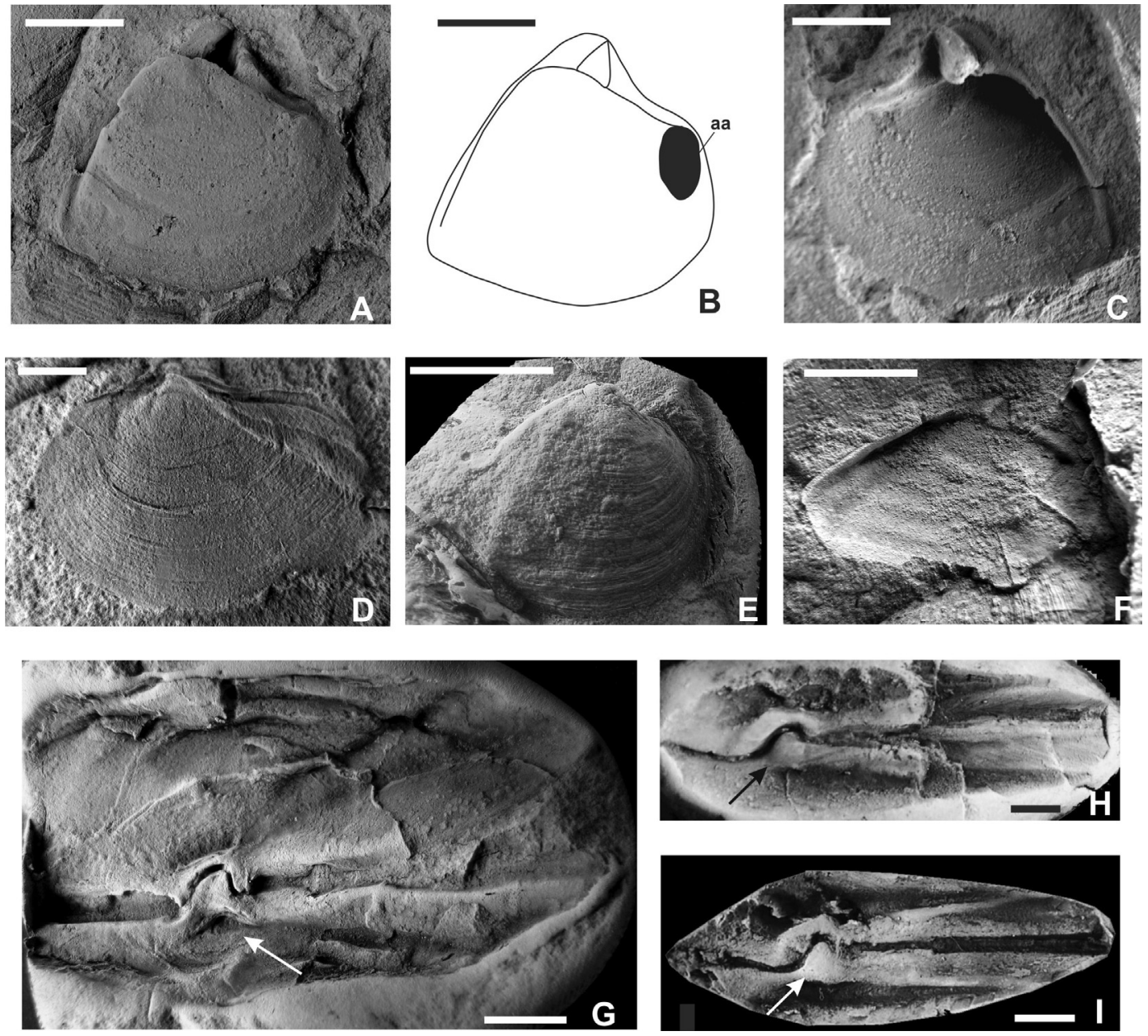

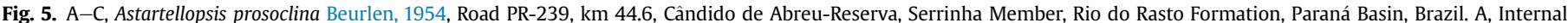

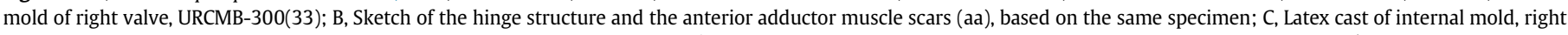

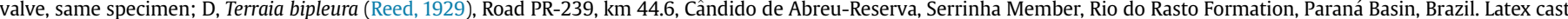

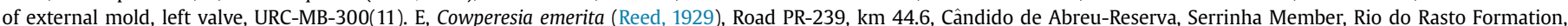

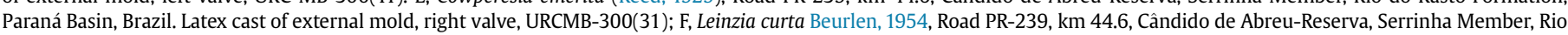

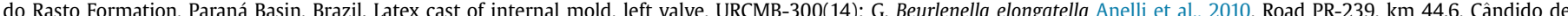

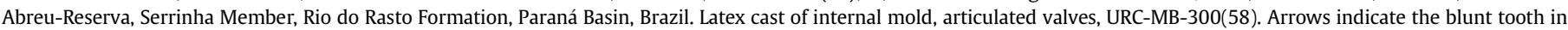

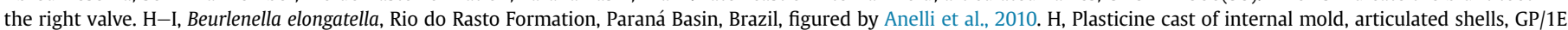
4825; I, Plasticine cast of internal mold, articulated shells, GP/1E 4815. Arrows indicate the blunt tooth in the right valve. All scale bars $=0.5 \mathrm{~cm}$.

Table 2

Measurements of Terraia bipleura (Reed, 1929).

\begin{tabular}{llll}
\hline Specimen code & Length $(\mathrm{mm})$ & Height $(\mathrm{mm})$ & Elongation $\mathrm{L} / \mathrm{H}$ \\
\hline URCMB-300 $(11)$ & 21.2 & 14.2 & 1.49 \\
URCMB-300(93) & 17.8 & 10.0 & 1.78 \\
\hline
\end{tabular}

(1952) and includes three species: Cowperesia anceps (Reed, 1935), C. emerita (Reed, 1929), and Cowperesia camposi Mendes, 1952. Runnegar and Newell (1971) suggested that this genus is a junior subjective synonym of Pyramus Dana, 1847 . However, according to some authors this synonymy does not seem to be valid (Mello, 1999; David et al., 2011, pp. 506-7). The present material closely resembles the specimens described as $C$. emerita by David et al. (2011) from the Permian Gai-As Formation, Huab area, Namibia. The external shell morphology as well as the ornamentation and the presence of two umbonal carinae are identical to those in C. emerita.
Table 3

Measurements of Astartellopsis prosoclina Beurlen, 1954.

\begin{tabular}{llll}
\hline Specimen code & Length $(\mathrm{mm})$ & Height $(\mathrm{mm})$ & Elongation $\mathrm{L} / \mathrm{H}$ \\
\hline URCMB-300(5b) & 18.7 & 14.9 & 1.25 \\
URCMB-300(6) & - & 15.5 & - \\
URCMB-300(19) & 13.1 & 9.0 & 1.45 \\
URCMB- 300(30a) & 30.6 & 25.0 & 1.22 \\
URCMB-300(30b) & 16.5 & 13.4 & 1.23 \\
URCMB-300(33) & 17.5 & 14.7 & 1.19 \\
URCMB-300(45) & - & - & - \\
URCMB-300(48b) & 13.3 & 11.4 & 1.16 \\
URCMB-300(53) & - & - & - \\
URCMB-300(61b) & - & - & - \\
URCMB-300(67a) & - & 13.0 & - \\
URCMB-300(89) & 18.8 & 16.8 & 1.11 \\
URCMB-300(133) & 14.0 & 11.8 & 1.18 \\
\hline
\end{tabular}

\section{Results and discussions}

\subsection{Assemblage composition}

In total, 66 bivalve specimens of the studied assemblage were 
Table 4

Measurements of Leinzia curta Beurlen, 1954.

\begin{tabular}{llll}
\hline Specimen code & Length $(\mathrm{mm})$ & Height $(\mathrm{mm})$ & Elongation $\mathrm{L} / \mathrm{H}$ \\
\hline URCMB-300(14a) & - & 8.8 & - \\
URMB-300(14b) & - & - & - \\
URCMB-300(68) & 26.4 & 11.2 & 2.35 \\
\hline
\end{tabular}

Table 5

Measurements of Beurlenella elongatella Anelli et al., 2010.

\begin{tabular}{llll}
\hline Specimen code & Length $(\mathrm{mm})$ & Height $(\mathrm{mm})$ & Width $(\mathrm{mm})$ \\
\hline URCMB-300 $(58)$ & - & - & 15.62 \\
\hline
\end{tabular}

Table 6

Measurements of Cowperesia emerita (Reed, 1929).

\begin{tabular}{llll}
\hline Specimen code & Length $(\mathrm{mm})$ & Height $(\mathrm{mm})$ & Elongation $\mathrm{L} / \mathrm{H}$ \\
\hline URCMB-300(21) & - & 9.9 & - \\
URCMB-300(28) & 12.6 & 8.6 & 1.46 \\
URCMB-300(31d) & 13.2 & 9.1 & 1.45 \\
URCMB-300(36) & 9.4 & 6.7 & 1.40 \\
URCMB-300(52) & - & 7.8 & - \\
URCMB-300(77) & 18.7 & 15.4 & 1.21 \\
URCMB-300(93b) & - & 11.0 & - \\
\hline
\end{tabular}

examined and described in this contribution. Other Permian assemblages of the Passa Dois Group are also cited and discussed below. The identified bivalves are referred to the following species: T. curvata, A. prosoclina, B. elongatella, T. bipleura, L. curta, and C. emerita (Table 7). Four of these species (T. bipleura, A. prosoclina, L. curta, and B. elongatella) are endemic to the Brazilian part of the Permian Paraná Basin. The most abundant species is T. curvata, followed by A. prosoclina and C. emerita (Table 7).

During the deposition of the basal to middle part of the Teresina Formation, assemblages were relatively diverse (at least 15 endemic species) and dominated by P. illusa, followed by Terraia aequilateralis and Plesiocyprinella carinata (Fig. 1, Table 8). These species were shallow burrowing suspension feeders (Runnegar and Newell, 1971; Simões et al., 1998; Ghilardi, 1999), which co-occur with other infaunal (intermediate and deep burrowering) bivalves and rare epi-byssate species (Coxesia mezzalirai). These species thrived in fine-grained siliciclastic sediments in shallow, oxygenated marginal waters and were succeeded by members of the $P$. neotropica assemblage in the middle-upper parts of the Teresina Formation (Fig. 1, Table 9). The assemblage is dominated by P. neotropica, C. anceps and Naiadopsis lamellosus (Table 9), which thrived in shallow, quiet, oxygenated and saline waters with a minimum input of siliciclastic sediments, probably under dry weather conditions (Rohn, 1994, 2007). Thus, the studied fauna, dominated by Terrainae bivalves, distinctly differs from the

Table 7

Bivalve species composition, ecology and abundance of the Terraia curvata assemblage, Serrinha Member, Rio do Rasto Formation. Explanation: SIFMUSF, shallow infaunal, facultatively motile, unattached, suspension feeders; IIFMUSF, intermediate infaunal, facultatively motile, unattached, suspension feeders.

\begin{tabular}{lllrr}
\hline Unit & Species & Guild & \multicolumn{1}{c}{ N. } & \multicolumn{1}{c}{$\%$} \\
\hline Serrinha Mb. & Terraia curvata & SIFMUSF & 40 & 60.61 \\
& Astartellopsis prosoclina & SIFMUSF & 13 & 19.70 \\
& Cowperesia emerita & SIFMUSF & 7 & 10.61 \\
& Leinzia curta & SIFMUSF & 3 & 4.55 \\
& Terraia bipleura & SIFMUSF & 2 & 3.03 \\
& Beurlenella elongatella & IIFMUSF & 1 & 1.52 \\
Totals & & 66 & 100 \\
\hline
\end{tabular}

\section{Table 8}

Bivalve species composition, ecology and abundance of the Pinzonella illusa assemblage, Teresina Formation. Explanation: SIFMUSF, shallow infaunal, facultatively motile, unattached, suspension feeders; IIFMUSF, intermediate infaunal, facultatively motile, unattached, suspension feeders; DIFMSF, deep infaunal, facultatively motile, suspension feeders; ESBSF, epifaunal, stationary, byssate, suspension feeders; SIFMC, shallow infaunal, facultatively motile, chemosymbionts.

\begin{tabular}{lllrr}
\hline Unit & Species & Guild & \multicolumn{1}{l}{ N. } & \multicolumn{2}{c}{$\%$} \\
\hline Teresina Fm. & Pinzonella illusa & SIFMUSF & 437 & 50.87 \\
& Terraia aequilateralis & SIFMUSF & 96 & 11.18 \\
& Plesiocyprinella carinata & SIFMUSF & 93 & 10.83 \\
& Casterella gratiosa & IIFMUSF & 72 & 8.38 \\
& Favalia arcuata & SIFMUSF & 41 & 4.77 \\
& Houldhausiella elongate & SIFMUSF & 35 & 4.07 \\
& Ferrazia cardinalis & SIFMUSF & 34 & 3.96 \\
& Cowperesia anceps & IIFMUSF & 14 & 1.63 \\
& Roxoa corumbataiensis & DIFMSF & 12 & 1.40 \\
& Itatamba paraima & IIFMUSF & 6 & 0.70 \\
& Angatubia cowperesioides & SIFMUSF & 5 & 0.58 \\
& Runnegariella fragilis & SIFMUSF & 4 & 0.47 \\
& Coxesia mezzalirai & ESBSF & 4 & 0.47 \\
& Tambaquyra camargoi & SIFMC & 4 & 0.47 \\
& Othonella araguaiana & SIFMUSF & 2 & 0.23 \\
& & 859 & 100 \\
\hline
\end{tabular}

\section{Table 9}

Bivalve species composition, ecology and abundance, Pinzonella neotropica assemblage, Teresina Formation. Explanation: SIFMUSF, shallow infaunal, facultatively motile, unattached, suspension feeders; IIFMUSF, intermediate infaunal, facultatively motile, unattached, suspension feeders; SMSBSF, semi-infaunal, stationary, byssate, suspension feeders; DIFMSF, deep infaunal, facultatively motile, suspension feeders.

\begin{tabular}{lllrr}
\hline Unit & Species & Guild & N. & \multicolumn{1}{c}{$\%$} \\
\hline Teresina & Pinzonella neotropica & SIFMUSF & 498 & 74.44 \\
& Cowperesia anceps & IIFMUSF & 95 & 14.20 \\
& Naiadopsis lamellosus & SMSBSF & 62 & 9.27 \\
& Jacquesia brasiliensis & SIFMUSF & 7 & 1.05 \\
& Roxoa intricans & DIFMSF & 4 & 0.60 \\
& Holdhausiella elongata & SIFMUSF & 3 & 0.45 \\
Totals & & & 669 & 100 \\
\hline
\end{tabular}

preceding molluscan faunas, which were dominated by Pinzonellinae and Pachydomidae (Megadesmidae) bivalves (Simões et al., 1998). Therefore, the newly described bivalve assemblage in the basal part of the Rio do Rasto Formation, which is located nearly $25 \mathrm{~m}$ above the last occurrences of members of the Pinzonella fauna, records a geologically rapid faunal turnover in the Permian succession of the Paraná Basin.

\subsection{Faunal turnover and paleoenvironmental change}

As shown in Tables 7-9, bivalve assemblages found in the shallow water lithofacies of the basal and middle parts of the underlying Teresina Formation are much more diverse taxonomically and ecologically, with no significant change in bivalve life-habits over the deposition of this unit (Fig. 6). In marginal areas, wave energy was minimal and was dampened by friction along a broad shallow sea floor. During the deposition of the Teresina Formation, the marginal habitats of the Paraná epeiric sea experienced substantial salinity variations (Rohn, 2007). During more humid intervals, the area of the epeiric sea expanded considerably, and the waters were less saline. Concomitantly, sedimentation was primarily siliciclastic. In contrast, when dry weather conditions prevailed, the salinity increased, mixed siliciclastic-carbonate sedimentation occurred, and large areas of the basin margin were exposed (Rohn, 2007).

The transition between the Teresina and the Rio do Rasto 


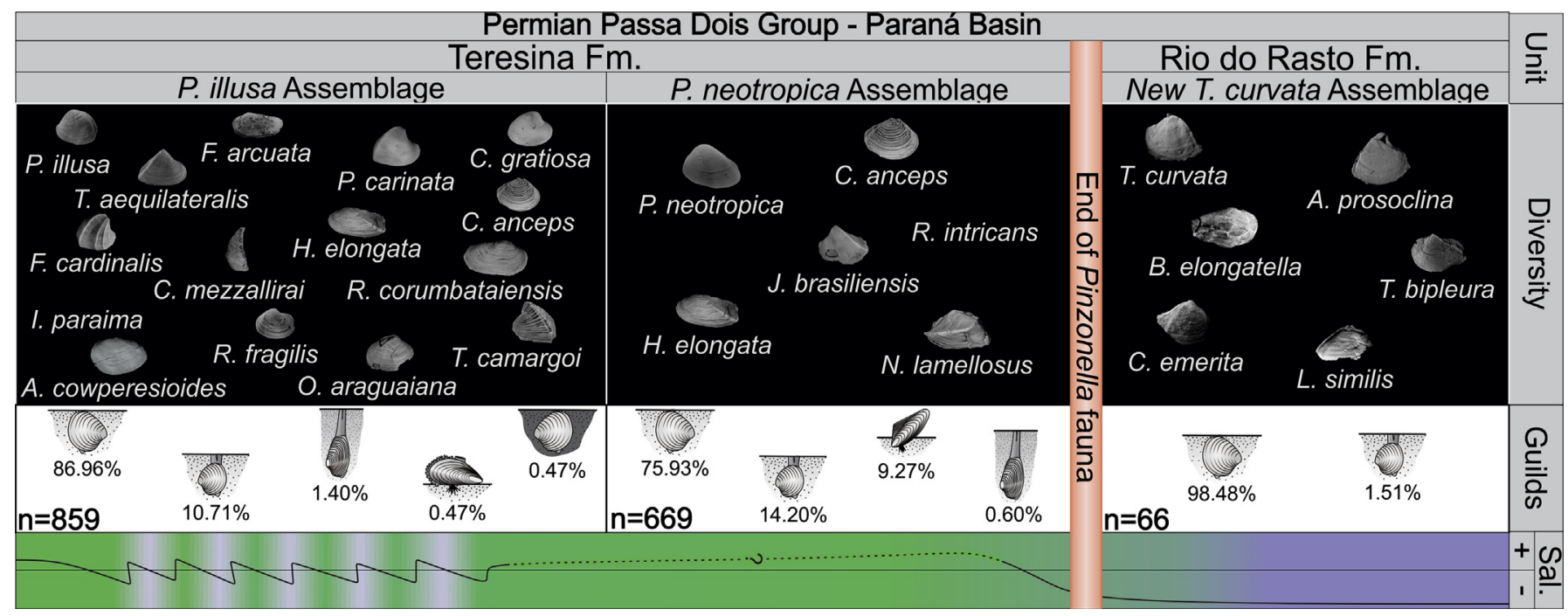

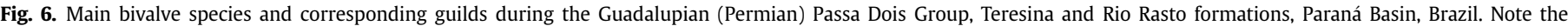
pronounced decrease in bivalve abundance, and the absence of pinzonellids and epifaunal bivalves in the base of the Rio do Rasto Formation.

Formation is marked by the abrupt appearance of conchostracans at the base of this last unit (Rohn, 1994, 2007). Thus, the freshening of the Paraná epeiric system increased significantly at this time (see also Ferreira-Oliveira and Rohn, 2010). Among the recorded conchostracan species, Monoleaia unicostata is one of the most abundant, showing a wide stratigraphic range (Rohn, 1988, 1994; Ferreira-Oliveira and Rohn, 2010) and occurring in direct association with the studied bivalves. The tendency of the water towards increased freshening at the end of the Permian Period in the Paraná Basin is also attested by the oxygen and carbon stable isotope values of eodiagenetic concretions of the Serrinha Member (Alessandretti et al., 2015), nearly $10 \mathrm{~m}$ above the contact with the underlying Teresina Formation. Additionally, $\delta^{13} \mathrm{C}$ data reveal low rates of primary productivity at the surface of the freshwater body (Alessandretti et al., 2015).

In the studied interval, an abrupt change of the plant assemblages also occurs, including the disappearance of lycopod plants and expansion of glossopterids, ferns, and sphenopsids (Rohn, 2007; but see Neregato et al., 2008; for the possible taphonomic control on plant preservation at the Teresina/Rio do Rasto transition). Thus, a major ecosystem change took place in the marginal environments of the Paraná Basin at that time. As indicated by our data, during the interval related to the basal parts of the Rio do Rasto Formation, major biotic changes in benthic communities involved loss of diversity, a drop in bivalve abundance and the establishment of a novel assemblage (Table 7, Fig. 6). Indeed, the studied stratigraphic interval is a record of a profound change in the gross taxonomic composition of bivalve assemblages, leading to the emergence of a taxonomically distinct fauna and a drop in the number of ecological guilds (Tables 10-12). The main faunal change is related to the shift in dominance between pinzonellin and terrain bivalves. Indeed, Pinzonellinae was the most abundant and widespread (stratigraphically and geographically) group throughout the Teresina Formation. Pachydomid bivalves, which were highly diverse throughout the Teresina Formation, declined to notably few species (B. elongatella and C. emerita) (Fig. 6). Thus, a key feature of the Serrinha assemblage is the lack of taxa that were abundant and diverse in pre-existing assemblages. Concomitantly, certain ecological guilds disappeared, such as the (a) epibyssate and (b) endobyssate suspension feeders, and deep infaunal suspension feeders (Table 7). The disappearance of epifaunal bivalves might be linked to changes in nutrient supply because the biomass of the
Table 10

Guild diversity and abundance of the bivalve mollusks in the Terraia curvata assemblage, Serrinha Member, Rio do Rasto Formation. Explanation: SIFMUSF, shallow infaunal, facultatively motile, unattached, suspension feeders; IIFMUSF, intermediate infaunal, facultatively motile, unattached, suspension feeders.

\begin{tabular}{llrc}
\hline Unit & Guild & N. & $\%$ \\
\hline Serrinha Mb. & SIFMUSF & 65 & 98.48 \\
& IIFMUSF & 1 & 1.51 \\
Totals & & 66 & 100 \\
\hline
\end{tabular}

Table 11

Guild diversity and abundance of the bivalve mollusks in the Pinzonella illusa assemblage, Teresina Formation. Explanation: SIFMUSF, shallow infaunal, facultatively motile, unattached, suspension feeders; IIFMUSF, intermediate infaunal, facultatively motile, unattached, suspension feeders; DIFMSF, deep infaunal, facultatively motile, suspension feeders; SIFMC, shallow infaunal, facultatively motile, chemosymbionts; ESBSF, epifaunal, stationary, byssate, suspension feeders.

\begin{tabular}{llrr}
\hline Unit & Guild & N. & $\%$ \\
\hline Teresina Fm. & SIFMUSF & 747 & 86.96 \\
& IIFMUSF & 92 & 10.71 \\
& DIFMSF & 12 & 1.40 \\
& SIFMC & 4 & 0.47 \\
& ESBSF & 4 & 0.47 \\
Totals & & 859 & 100 \\
\hline
\end{tabular}

Table 12

Guild diversity and abundance of the bivalve mollusks in the Pinzonella neotropica assemblage, Teresina Formation. Explanation: SIFMUSF, shallow infaunal, facultatively motile, unattached, suspension feeders; IIFMUSF, intermediate infaunal, facultatively motile, unattached, suspension feeders; SMSBSF, semi-infaunal, stationary, byssate, suspension feeders; DIFMSF, deep infaunal, facultatively motile, suspension feeders.

\begin{tabular}{llrc}
\hline Unit & Guild & N. & $\%$ \\
\hline Teresina Fm. & SIFMUSF & 508 & 75.93 \\
& IIFMUSF & 95 & 14.20 \\
& SMSBSF & 62 & 9.27 \\
Totals & DIFMSF & 4 & 0.60 \\
& & 669 & 100 \\
\hline
\end{tabular}

sessile epifauna decreases profoundly with a decline in nutrient availability (Birkeland, 1977) and freshening events (Stockton, 1984) as well as the disappearance of coarse stable substrates. 
The species diversity and abundance of bivalves partitioned by their life habits also changed intensely. The new assemblage is dominated by shallow-infaunal suspension feeders, especially T. curvata and A. prosoclina (Tables 7 and 10). Thus, with respect to the range of bivalve modes of life, the novel assemblage is ecologically impoverished. However, due to the diversification of the Terrainae, the species diversity of the novel assemblage is similar to that of the preceding assemblage from the top of the Teresina Formation (Table 8). Concomitantly, the diversity of selected marine groups, such as the pachydomid bivalves, which were the most diverse infaunal group during the deposition of the Teresina Formation, dropped markedly (Tables 7-9, Fig. 6).

The faunal turnover coincides with an interval of pronounced freshwater influence that could account for the disappearance of the pre-existing dominant bivalve groups, such as the Pinzonellinae. Freshening of the marginal settings of the Paraná Basin during the deposition of the Serrinha Member is attributed to the prevalence of more humid conditions (Rohn, 1994; Simões et al., 2012; Alessandretti et al., 2015). Indeed, Wesselingh (2007) noticed that extreme faunal turnovers in molluscan faunas that thrived in epeiric seas or long-lived lakes might be partially linked to climate change and periods of pronounced freshening as well as food-web changes (see also Todd et al., 2002; Pfuhl and McCave, 2007). In other words, our data favor a marked facies change at the base of the Rio do Rasto Formation, which reflects a deep environmental change, the main reason for the turnover in bivalve composition. After that, any new mode of life was originated, because all Permian bivalves of the overlying Morro Pelado Member (see Simões et al., 1998) were shallow infaunal burrowing and suspension feeders. Therefore, a pronounced loss of functional diversity occurred at the regional scale, indicating an ecologically depauperate condition of the marginal benthic ecosystems of the Paraná Basin (Fig. 6).

\subsection{Climate change, freshening events and the lessons from the fossil record}

The Teresina-Rio do Rasto succession of the Permian Passa Dois Group in Brazil is a historical archive of data of endemic bivalve community reactions to regional paleoenvironmental changes (see Simões et al., 1998). During the interval documented by the Rio do Rasto Formation, a vast epicontinental freshwater body fed by fluvio-deltaic systems existed in the Paraná Basin (Warren et al., 2008; Alessandretti et al., 2015, Fig. 10). Continentalization of this body of water, coupled with climatic and hydrological changes (freshening), was accompanied by a benthic community crisis in the marginal habitats, as represented by the disappearance of $>80 \%$ of preexisting genera and $60 \%$ of bivalve ecological guilds.

In the studied sedimentary succession, the most diverse and abundant assemblages (see Tables 8 and 9) are those found in the middle part of the Teresina Formation (P. illusa assemblage), when a number of shallow-water benthic microhabitats existed in the basin, including fine-grained siliciclastic-dominated bottoms, bioclast-rich sandy substrates, and hypersaline carbonatedominated settings (Fig. 6). Shallow well oxygenated aerated waters prevailed during this phase of high habitat heterogeneity and niche departmentalization. Closed articulated bivalves, certain of which are preserved in growth position, are found in a number of substrates, showing that distinct species thrived in different bottoms. The impoverished assemblages of the uppermost portion of the Teresina Formation $P$. neotropica assemblage (when most of preexisting species and guilds disappeared; see Tables 10-12) indicates increasing stress conditions. After this, epifaunal bivalves vanished from the benthic communities of the Paraná Basin. The T. curvata assemblage in the basal part of the Rio do Rasto Formation includes newly evolved genera and species, which infaunally colonized the soft bottoms of the freshened marginal habitats of the Paraná Basin. Indeed, $\delta^{18} \mathrm{O}$ values recently recorded from early diagenetic carbonate concretions of the Serrinha Member indicate freshwater conditions rather than marine ones (Alessandretti et al., 2015). As argued above, appearance of this assemblage is linked to the input of freshwater into basin margins as a response to more humid conditions (see also Rohn, 1994). In fact, the negative $\delta^{18} \mathrm{O}$ values recorded in the carbonate cement and fracture fills of concretions of the Serrinha Member appear to be related to the decreasing salinity in the epeiric basin (Alessandretti et al., 2015). According to these authors, this effect was primarily governed by the discharge of meteoric waters from continental runoff, rivers and rains. Thus, stratigraphical, sedimentological and paleontological data coupled with geochemical evidence indicate that the (a) onset of diversity and abundance losses, (b) extinction of longlived endemic species, (c) guild impoverishment, and (d) expansion of infaunal bivalves coincide with intervals of climate-driven freshening of marginal habitats of the Paraná Basin. Similar phenomena are recorded in present-day temperate and polar environments, in which the influx of freshwater during the summer in marine settings is an important stressor acting on shallow water benthos (Smale and Barnes, 2008 and references therein). Due to glacial and ice shelf melting, the coastal waters of various regions are experiencing a considerable increase in freshwater input (=freshening, see Jacobs et al., 2002), which influences those marine benthos living in very shallow waters (Smale and Barnes, 2008). The studied regional Permian example shows that freshening events could indeed influence the local bivalve community. For example, in our case study, the disappearance of epifaunal bivalves coincides with the interval when the marginal waters of the Paraná Basin were freshened (see also Simões et al., 1998). Interesting, Stockton (1984) observed mass mortality in an epifaunal pectinid bivalve population following the summer formation of a hyposaline lens of seawater at McMurdo Sound, Antarctica. In this context, the recorded faunal turnover in bivalve assemblages inhabiting the shallow waters of the margins of the Paraná Basin might offer some clues to the benthic responses to climate change and ocean freshening (i.e., hyposaline conditions) (see also Peltier, 2007).

\subsection{Biocorrelation and paleogeography}

Rohn (1994) suggested that the basal part of the Serrinha Member in the Rio do Rasto Formation could represent the stratigraphic range of a new bivalve biozone lying between the P. neotropica and Lenzia similis biozones (sensu Rohn, 1994). Our results support this assumption. According to current knowledge, the vertical range of four studied species (T. curvata, A. prosoclina, L. curta, and $B$. elongatella) is restricted to the basal part of the Serrinha Member. In other words, these species are not recorded in other bivalve assemblages of the Permian Passa Dois Group (see Rohn, 1994). Additionally, members of the overlying L. similis Biozone are absent.

Despite the high degree of endemism, the studied bivalve assemblage can be correlated with that of the Permian Gai-As Formation (David et al., 2011) in the Huab region of Namibia, which shares in common at least two species (T. curvata and C. emerita). Radiometric dating of zircon grains from tuff beds between two bivalve horizons within the upper part of the Gai-As Formation provide U/PB ages of $265 \pm 2.5$ Ma (Holzförster, 2000, 2002; Wanke, 2000). These data reinforce the idea of a hydrological connection (seaway) between the Paraná and Huab basins during the Guadalupian Epoch (Holzförster, 2000, 2002; Wanke, 2000; David et al., 2011). 


\section{Summary and concluding remarks}

During the Guadalupian Epoch of the Permian Period, the Paraná Basin was an immense and confined epeiric sea with hydrological connections (seaway) to the Huab Basin of Namibia. Within this shallow body of water, successive endemic bivalve faunas developed (Fig. 1). The Rio do Rasto Formation records the last progradational cycle tied to the complete continentalization of the basin (Rohn, 1994; Warren et al., 2008; Holz et al., 2010; Alessandretti et al., 2015). The basal part of this unit (i.e., Serrinha Member) was deposited under shallow-water conditions punctuated by storms and episodic deltaic incursions (Warren et al., 2008; Alessandretti et al., 2015). Geologically rapid and extreme faunal turnover is recorded in the Serrinha Member, which is believed to be linked to regional-scale paleo-environmental changes and shifts in the sedimentary regime. In this study, we demonstrate that the composition and ecological structure of the bivalve assemblage in the basal Serrinha Member is distinct from those recorded in the underlying Teresina Formation and the overlying Morro Pelado Member of the Rio do Rasto Formation. The recorded evolutionary turnover of bivalves correlates with taphonomic, sedimentologic and geochemical data that indicate pronounced freshening of the marginal settings of the Paraná Basin. The faunal transition is tied to basinal-scale salinity variations and changes in primary productivity, which are both associated with the progressive continentalization of the Paraná Basin coupled with climatic variations (alterations between more arid and humid intervals). Therefore, changes in salinity demonstrably primarily controlled the faunal turnover in the studied Permian interval of the Paraná Basin, a condition already recognized in other Paleozoic (Zampito et al., 2012) and Cenozoic (Wesselingh, 2007, 2008) invertebrate faunas.

Although species-level diversity persisted in the new assemblage, the preceding dominant bivalve group (Pinzonellinae) disappeared. In addition, the diversity of the Pachydomidae (a typical marine bivalve group with the widest stratigraphic range in the Passa Dois Group) dropped dramatically. Thus, the transition between the Teresina and Rio do Rasto formations marks the onset of extinction and loss of typical members of the "Pinzonella" fauna, including (among others) shallow (Pinzonella, Plesiocyprinella and Holdhausiella), intermediate (Casterella and Cowperesia) and deep (Roxoa) infaunal suspension feeders plus semi-infaunal (Naiadopsis) and epifaunal (Coxesia) byssate forms. The lack of the epifaunal and semi-infaunal byssate suspension-feeding bivalves and the dominance of shallow infaunal bivalves is a signature of the novel assemblage. This evidence indicates conditions of high environmental stress outside the range of the fluctuations witnessed during the deposition of the Teresina Formation (for additional similar examples, see Aberhan and Kiessling, 2015). Furthermore, this evidence confirms that the crisis affected bivalves in different ways (i.e., it was selective; see also Foster and Twitchett, 2014) and that the responses varied between taxa (e.g., Pinzonella versus Terraia), guilds (e.g., infaunal versus epifaunal bivalves), or clades (e.g., edmondioids versus crassatelloids).

Finally, our data can offer a snapshot of the impact of climaticdriven changes in coastal benthic ecosystems and offer some clues of bivalve fauna responses to climatic-induced releases of freshwater (i.e., freshening events) in marginal settings of presentday oceans. A biotic crisis characterized by (a) annihilation of members of local fauna coupled with changes in (b) species dominance, (c) abundance and (d) a decrease in ecological guilds is expected in such regional environmental scenario.

\section{Acknowledgments}

Financial support was provided by FAPESP (Grant 2011/01975-0) and CNPq (Grants 500694/92-3, 151853/2008-8). We thank Oscar Rösler and Jean-René Ribeiro Penatti (Baker Hughes) for their help during the field campaigns. The taxonomic analysis was conducted as part of the Ph.D. thesis of J.M.D. Franz T. Fürsich and Arturo C. Taboada provided detailed revisions and constructive suggestions, which improved considerably the final version of this paper. Our thanks are also extended to the Department of Zoology, IBB/UNESP and Department of Sedimentary and Environmental Geology, IGc/ USP, which provided laboratory and logistic facilities.

\section{References}

Aberhan, M., Kiessling, W., 2015. Persistent ecological shifts in marine molluscan assemblages across the end-Cretaceous mass extinction. In: Proceedings of the National Academy of Sciences, pp. 1-6. Early Edition. http://dx.doi.org/10.1073/ pnas.1422248112.

Alessandretti, L., Warren, L.V., Machado, R., Noveloo, V.F., Sayeg, I.J., 2015. Septarian carbonate concretions in the Permian Rio do Rasto Formation: birth, growth and implications for the early diagenetic history of southwestern Gondwana succession. Sediment. Geol. 326, 1-15. http://dx.doi.org/10.1016/j.sedgeo.2015. 06.007.

Anelli, L.E., Simões, M.G., David, J.M., 2010. A new permian bivalve (Megadesmidae, Plesiocyprinellinae) from the serrinha member, Rio do rasto formation, paraná Basin, Brazil. Geol. USP Sér. Cient. 10, 13-21. http://dx.doi.org/10.5327/Z1519874X2010000200002.

Beurlen, K., 1954. As faunas de lamelibrânquios do sistema gonduânico no Paraná. In: Lange, F.W. (Ed.), Volume Comemorativo Do 1. Centenário do Estado do Paraná, Curitiba, pp. 107-136.

Birkeland, C. 1977. The importance of rate of biomass accumulation in early successional stages of benthic communities to the survival of coral recruits. In: Proceedings of the Third International Symposium on Coral Reefs, pp. 15-21.

Carter, J.G., Altaba, C.R., Anderson, L.C., Araujo, R., Biakov, A.S., Bogan, A.E., Campbell, D.C., Campbell, M., Jin-Hua, C., Cope, J.C.W., Delvene, G., Dijkstra, H.H., Zong-Jie, F., Gardner, R.N., Gavrilova, V.A., Goncharova, I.A., Harries, P.J., Hartman, J.H., Hautmann, M., Hoeh, W.R., Hylleberg, J., Bao-Yu, J., Johnston, P., Kirkendale, L., Kleeman, K., Hoppka, J., Kriz, J., Machado, D., Malchus, N. Márquez-Aliaga, A., Masse, J.P., Mcroberts, C.A., Middelfart, P.U., Mitchell, S., Nevesskaja, L.A., Özer, S., Pojeta, J.J., Polubotko, I.V., Pons, J.M., Popov, S., Sánchez, T., Sartori, A.F., Scott, R.W., Sey, I.I., Signorelli, J.H., Silantiev, V.V., Skelton, P.W., Thomas, S., Waterhouse, J.B., Wingard, G.L., Yancey, T., 2011. A synoptical classification of the bivalvia (Mollusca). Paleontol. Contrib. 4, 1-47. http://dx.doi.org/10.13140/2.1.3833.4402.

Cox, L.R., 1934. Triassic Lamellibranchia from Uruguay. Ann. Mag. Nat. Hist. 13, 264-273. http://dx.doi.org/10.1080/00222933408654809.

Dall, W.H., 1889. On the hinge of pelecypods and its development, with an attempt toward a better subdivision of the group. Am. J. Sci. 38, 445-462. http://dx.doi. org/10.2475/ajs.s3-38.228.445.

Dana, J.D., 1847. Descriptions of fossil shells of the collections of the exploring expedition under the command of Charles Wilkes, U.S.N., obtained in Australia, from the lower layers of the coal formation in Illawarra, and from a deposit probably of nearly the same age at Harper's Hill, Valley of the Hunter. Am. J. Sci. Arts 4, 1151-1160.

David, J.M., 2010. Bivalves permianos da fase de continentalização das bacias do Gondwana ocidental: sistemática, paleogeografia e bioestratigrafia. IGCE-Universidade Estadual Paulista. Master thesis.

David, J.M., Simões, M.G., Anelli, L.E., Rohn, R., Holzförster, F., 2011. Permian bivalve molluscs from the Gai-As Formation, northern Namibia: systematics, taphonomy and biostratigraphy. Alcheringa Australas. J. Palaeontol. 35, 497-516. http://dx.doi.org/10.1080/03115518.2011.538908.

Ferreira-Oliveira, L.G., Rohn, R., 2010. Leaiid conchostracans from the uppermost Permian strata of the Paraná Basin, Brazil: chronostratigraphic and paleobiogeographic implications. J. S. Am. Earth Sci. 29, 371-380. http://dx.doi.org/ 10.1016/j.jsames.2009.03.006.

Férussac, A.E., 1822. Tableaux systématiques des animaux mollusques. A. Bertrand, Paris and London.

Fischer, P.H., 1887. Manuel de Conchyliologie et de Paléontologie Conchyliologique, ou Histoire Naturelle des Mollusques Vivants et Fossiles. F. Savy, Paris, pp. 1009-1369. http://dx.doi.org/10.5962/bhl.title.13213.

Foster, W.J., Twitchett, R.J., 2014. Functional diversity of marine ecosystems after the late Permian mass extinction event. Nat. Geosci. 7, 233-238. http://dx.doi.org/ 10.1038/ngeo2079.

Fürsich, F.T., Aberhan, M., 1990. Significance of time-averaging for paleocommunity analysis. Lethaia 23, 143-152. http://dx.doi.org/10.1111/j.1502-3931.1990. tb01355.x.

Gama Jr., E., 1979. A sedimentação do Grupo Passa Dois (exclusive Formação Irati), um modelo geomórfico. Rev. Bras. Geociênc. 9, 1-16.

Ghilardi, R.P., 1999. Paleoautoecologia dos bivalves do Grupo Passa Dois 
(Neopermiano) no Estado de São Paulo: bivalves fósseis como indicadores da dinâmica sedimentar. IGc-Universidade de São Paulo. Master thesis.

Hertwig, C.W.T.R., 1895. Lehrbuch der Zoologie. Gustav Fischer, Boulder. http://dx. doi.org/10.5962/bhl.title.1695.

Holdhaus, K., 1918. Sobre alguns lamelibrânquios fósseis do sul do Brasil. Serv. Geol. Miner. 2, 1-24.

Holz, M., França, A.B., Souza, P.A., Iannuzzi, R., Rohn, R., 2010. A stratigraphic chart of the late Carboniferous/Permian succession of the eastern border of the Paraná Basin, Brazil, South America. J. S. Am. Earth Sci. 29, 381-399. http://dx.doi.org/ 10.1016/j.jsames.2009.04.004.

Holzförster, F., 2000. Sedimentology, Stratigraphy and Synsedimentary Tectonics of the Karoo Supergroup in the Huab and Waterberg-erongo Areas, N-Namibia. University of Würzburg. Ph.D. thesis.

Holzförster, F., 2002. Sedimentology, stratigraphy and synsedimentary tectonics of the Karoo supergroup in the Huab and Waterberg-Erongo areas, N-Namibia. Beringeria 30, 1-144.

Jacobs, S.S., Giulivi, C.F., Mele, P.A., 2002. Freshening of the Ross Sea during the late 20th century. Science 297 (386). http://dx.doi.org/10.1126/science.1069574.

Kidwell, S.M., Fürsich, F.T., Aigner, T., 1986. Conceptual framework for the analysis of fossil concentrations. Palaios 1, 228-238. http://dx.doi.org/10.2307/3514687.

King, W., 1844. On a new genus of Palaeozoic shells. Ann. Mag. Nat. Hist. 14, $313-317$.

King, W., 1850. Monograph of the Permian fossils of England. Palaeontogr. Soc. $1-253$.

Lavina, E.L., 1991. Geologia sedimentar e paleogeografia do Neopermiano e Eotriássico (Intervalo Kazaniano - Scythiano) da Bacia do Paraná. Universidade Federal do Rio Grande do Sul. Ph.D. thesis.

Limarino, C.O., Césari, S.N., Spalletti, L.A., Taboada, A.C., Isbell, J.L., Geuna, S., Gulbranson, E.L., 2014. A paleoclimatic review of southern South America during the late Paleozoic: a record from icehouse to extreme greenhouse conditions. Gondwana Res. 25, 1396-1421. http://dx.doi.org/10.1016/j.gr.2012. 12.022 .

Mello, L.H.C., 1999. Análise claíistica dos bivalves do Grupo Passa Dois (Neopermiano), Bacia do Paraná, Brasil: implicações taxonômicas, evolutivas e paleobiogeográficas. IGc-Universidade de São Paulo. Master thesis.

Mendes, J.C., 1949.

Mendes, J.C., 1952. A Formação Corumbataí na região do Rio Corumbataí. (Estratigrafia e descrição dos lamelibrânquios). Bol. Fac. Filos. Ciênc. Let. Univ. São Paulo Geol. 145, 1-119.

Mendes, J.C., 1954. Contribuição à estratigrafia da Série Passa Dois no Estado do Paraná. Boletim da Faculdade de Filosofia. Ciênc. Let. Univ. São Paulo Geol. 175, $1-119$.

Morris, N.J., Dickins, J.M., Astafieva-Urbaitis, K., 1991. Upper paleozoic Anomalodesmatan Bivalvia. Bull. Br. Mus. Nat. Hist. Geol. 47, 51-100.

Neregato, R., Souza, P.A., Rohn, R., 2008. Registros palinológicos inéditos nas formações Teresina e Rio do Rasto (Permiano, Grupo Passa Dois, Bacia do Paraná): implicações biocronoestratigráficas e paleoambientais. Pesqui. Geociênc. 35, $9-21$.

Newell, N.D., 1965. Classification of the Bivalvia. Am. Mus. Novit. 2206, 1-25.

Peltier, W.R., 2007. Rapid climate change and Arctic Ocean freshening. Geology 35, 1147-1148. http://dx.doi.org/10.1130/focus122007.1.

Pfuhl, H.A., McCave, I.N., 2007. The Oligocene-Miocene boundary: cause and consequence from a southern ocean perspective. In: Willians, M., Haywood, A.M., Gregory, F.J., Schmidt, D.N. (Eds.), Deep Time Perspectives on Climate Change: Marrying the Signal from Computer Models and Biological Proxies. The Micropalaeontological Society Special Publications, London, pp. 389-407.

Reed, f.r.c., 1929. Faunas Triassicas do Brasil. Serv. Geol. Miner. do Bras. 9, 1-83.

Reed, F.R.C., 1935. Some Triassic lamellibranchs from Brazil and Paraguay. Geol. Mag. 72, 33-42. http://dx.doi.org/10.1017/S0016756800092311.

Ridewood, W.G., 1903. On the structure of the gills of the Lamellibranchia. R. Soc. Lond. Philos. Trans. Ser. B Biol. Sci. 195, 147-284. http://dx.doi.org/10.1098/rstb. 1903.0005.

Rohn, R., 1988. Bioestratigrafia e paleoambientes da Formação Rio do Rasto na borda leste da Bacia do Paraná (Permiano Superior, Estado do Paraná). IGc-Universidade de São Paulo. Master thesis.

Rohn, R., 1994. Evolução ambiental da Bacia do Paraná durante o Neopermiano no leste de Santa Catarina e do Paraná. IGc-Universidade de São Paulo. Ph.D. thesis.

Rohn, R., 2007. The passa dois group (Paraná Basin, permian): investigations in progress. In: Extended Abstracts - I Workshop "Problems in the Western Gondwana Geology, South America - Africa correlations: du Toit revisited, pp. 151-157.

Rohn, R., Simões, M.G., 1997. Pelecypods of the basal Serrinha Member (Rio do Rasto
Formation, Passa Dois Group, Upper Permian) at the Reserva-Cândido de Abreu region of the Paraná State. In: Boletim de Resumos do XV Congresso Brasileiro de Paleontologia, pp. 1-72.

Rohn, R., Lourenço, A.T.A., Meglhioratti, T., 2003. As formações Serra Alta, Teresina e Rio do Rasto no furo de sondagem SP-23-PR (Permiano, Grupo Passa Dois, Borda Leste da Bacia do Paraná). In: Resumos do II Congresso Brasileiro de P\&D em Petróleo e Gás, p. 40.

Runnegar, B., 1974. Evolutionary history of the bivalve subclass Anomalodesmata. J. Paleontol. 48, 904-939.

Runnegar, B., Newell, N.D., 1971. Caspian- like relict moluscan fauna in the South America Permian. Bull. Am. Mus. Nat. Hist. 146, 1-66.

Scarlato, O., Starobogatov, Y.I., 1979. Osnovye cherty evoliutsii I Sistema klassa Bivalvia. Tr. Zool. Inst. 80, 5-38.

Schemiko, D.C.B., Vesely, F.F., Fernandes, L.A., Sowek, G.A., 2014. Distinção dos elementos deposicionais fluviais, eólicos e lacustres do Membro Morro Pelado Permiano Superior da Bacia do Paraná. Geol. USP Sér. Cient. 14, 29-46. http:// dx.doi.org/10.5327/Z1519-874X201400030003.

Schneider, R.L., Muhlmann, H., Tommasi, E., Medeiros, R.A., Daemon, R.F., Nogueira, A.A., 1974. Revisão estratigráfica da Bacia do Paraná. In: Anais do XXVIII Congresso Brasileiro de Geologia, pp. 41-65.

Simões, M.G., Marques, A.C., Mello, L.H.C., Anelli, L.E., 1997. Philogenetic analysis of the genera of the extinct family Megadesmidae (Pelecypoda, Anomalodesmata) with remarks on its paleoecology and taxonomy. J. Comput. Biol. 2, 75-90.

Simões, M.G., Rocha-Campos, A.C., Anelli, L.E., 1998. Paleoecology and evolution of Permian pelecypod assemblages (Paraná Basin) from Brazil. In: Johnston, P.A., Haggart, J.W. (Eds.), Bivalves - an Eon of Evolution: Paleobiological Studies Honoring Norman D. Newell. University of Calgary Press, Calgary, pp. 443-452.

Simões, M.G., Quaglio, F., Warren, L., Anelli, L.E., Stone, P., Riccomini, C., Grohmann, C.H., Chamani, M.A.C., 2012. Permian non-marine bivalves of the Falkland Islands and their palaeoenvironmental significance. Alcheringa 36, 1-13. http://dx.doi.org/10.1080/03115518.2012.688682.

Smale, D.A., Barnes, D.K.A., 2008. Likely responses of the Antarctic benthos to climate-related changes in physical disturbance during the 21 st century, based primarily on evidence from the West Antarctic Peninsula region. Ecography 31, 289-305. http://dx.doi.org/10.1111/j.0906-7590.2008.05456.x.

Stanley, S.M., 1970. Relation of shell form to life habits of the Bivalvia (Mollusca). Mem. Geol. Soc. Am. 125, 1-296. http://dx.doi.org/10.1130/MEM125-p1.

Stockton, W.L., 1984. The biology and ecology of the epifaunal scallop Adamussium colbecki on the west side of McMurdo Sound, Antarctica. Mar. Biol. 78, 171-178. http://dx.doi.org/10.1007/BF00394697.

Todd, J.A., Jackson, J.B., Johnson, K.G., Fortunato, H.M., Heitz, A., Alvarez, M., Jung, P., 2002. The ecology of extinction: molluscan feeding and faunal turnover in the Caribbean Neogene. Proc. R. Soc. Lond. B 269, 571-577. http://dx.doi.org/10. 1098/rspb.2001.1923.

Wanke, A., 2000. Karoo- Etendeka Uncoformites in NW Namibia and Their Tectonic Implications. Würzburg University. Ph.D. thesis.

Warren, L.V., 2005. Evolução sedimentar da Formação Rio do Rasto na região centro-sul do Estado de Santa Catarina. Master thesis. IGc-Universidade de São Paulo.

Warren, L.V., Almeida, R.P., Hachiro, J., Machado, R., Roldan, L.F., Steiner, S.S., Chamani, M.A.C., 2008. Evolução sedimentar da Formação Rio do Rasto (Permo-Triássico da Bacia do Paraná) na porção centro sul do estado de Santa Catarina, Brasil. Rev. Bras. Geociênc. 38, 213-227.

Warren, L.V., Assine, M.L., Simões, M.G., Riccomini, C., Anelli, L.E., 2015. A Formação Serra Alta, Permiano, no Centro-Leste do Estado de São Paulo, Bacia do Paraná, Brasil. Braz. J. Geol. 45, 127-142. http://dx.doi.org/10.1590/ 23174889201500010008.

Wesselingh, F.P., 2007. Long-lived lake molluscs as island faunas: a bivalve perspective. In: Renema, W. (Ed.), Biogeography, Time and Place: Distributions, Barriers and Islands. Springer, Dordrecht, pp. 275-314. http://dx.doi.org/10. 1007/978-1-4020-6374-9_9.

Wesselingh, F.P., 2008. Molluscan radiations and landscape evolution in miocene Amazonia. Ann. Univ. Turku. Finl. Sar. Ser. AII OSA Tom 232, 1-44.

Wesselingh, F.P., Räsänen, M.E., Irion, G., Vonhof, H.B., Kaandorp, R., Renema, W., Romero Pittman, L., Gingras, M., 2002. Lake Pebas: a palaeoecological reconstruction of a Miocene, long-lived lake complex in western Amazonia. Cainozoic Res. 1, 35-81.

Zampito, J.J., Brett, C., Baird, G.C., 2012. The late Middle Devonian (Givetian) global Taghanic biocrisis in its type area (Northern Appalachian Basin): geologically rapid faunal transitions driven by global and local environmental changes. In: Talent, J.A. (Ed.), Earth and Life: International Year of Planet Earth. Springer, pp. 677-703. 